See Mun Lee, Kong Mun Lo and Edward R.T. Tiekink*

\title{
Crystal structure of bromido-tri(4-chlorophenyl- $\mathrm{K}^{1} \mathrm{C}$ )-(ethanol-k $\left.{ }^{1} O\right)$ tin (IV) - 4,4'-dimethyl-2,2'- bipyridine (2/1), $\mathrm{C}_{52} \mathrm{H}_{48} \mathrm{Br}_{2} \mathrm{Cl}_{6} \mathrm{~N}_{2} \mathrm{O}_{2} \mathrm{Sn}_{2}$
}

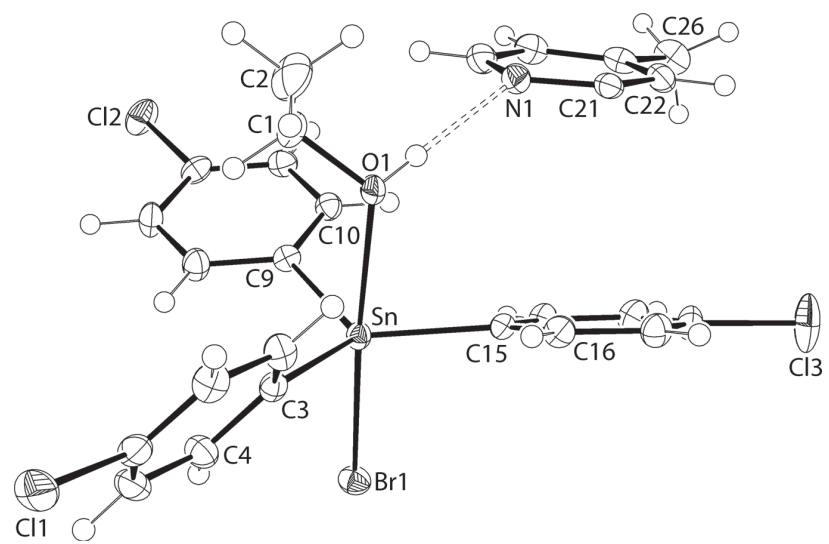

https://doi.org/10.1515/ncrs-2019-0542

Received July 29, 2019; accepted August 12, 2019; available online October 18, 2019

\section{Abstract \\ $\mathrm{C}_{52} \mathrm{H}_{48} \mathrm{Br}_{2} \mathrm{Cl}_{6} \mathrm{~N}_{2} \mathrm{O}_{2} \mathrm{Sn}_{2}$, triclinic, $P \overline{1}$ (no. 2), $a=8.8297$ (1) $\AA$, $b=12.2632(2) \AA, \quad c=12.6884(2) \AA, \quad \alpha=84.191(1)^{\circ}$, $\beta=83.940(1)^{\circ}, \quad \gamma=76.086(1)^{\circ}, \quad V=1322.04(3) \AA^{3}, \quad Z=1$, $R_{\mathrm{gt}}(F)=0.0222, w R_{\text {ref }}\left(F^{2}\right)=0.0621, T=100(2) \mathrm{K}$.}

\section{CCDC no.: 1946596}

The components of the asymmetric unit are shown in the figure. Table 1 contains crystallographic data and Table 2 contains the list of the atoms including atomic coordinates and displacement parameters.

\section{Source of material}

General: All chemicals and solvents were used as purchased without purification. The melting point was determined using a Mel-temp II digital melting point apparatus and was uncorrected. The solid-state IR spectrum was obtained on a Bruker

*Corresponding author: Edward R.T. Tiekink, Research Centre for Crystalline Materials, School of Science and Technology, Sunway University, 47500 Bandar Sunway, Selangor Darul Ehsan, Malaysia, e-mail: edwardt@sunway.edu.my. https://orcid.org/0000-00031401-1520

See Mun Lee and Kong Mun Lo: Research Centre for Crystalline Materials, School of Science and Technology, Sunway University, 47500 Bandar Sunway, Selangor Darul Ehsan, Malaysia
Table 1: Data collection and handling.

\begin{tabular}{ll}
\hline Crystal: & Colourless prism \\
Size: & $0.10 \times 0.08 \times 0.05 \mathrm{~mm}$ \\
Wavelength: & Cu $K \alpha$ radiation $(1.54184 \AA$ A $)$ \\
$\mu:$ & $12.4 \mathrm{~mm}^{-1}$ \\
Diffractometer, scan mode: & XtaLAB Synergy, $\omega$ \\
$\theta_{\text {max }}$, completeness: & $67.0^{\circ},>99 \%$ \\
$N(h k l)_{\text {measured }}, N(h k l)_{\text {unique }}, R_{\text {int }}:$ & $31356,4730,0.038$ \\
Criterion for $I_{\text {obs }}, N(h k l)_{\mathrm{gt}}:$ & $I_{\text {obs }}>2 \sigma\left(I_{\text {obs }}\right), 4577$ \\
$N(\text { param })_{\text {refined }}:$ & 303 \\
Programs: & CrysAlis ${ }^{\text {PRO }}[1]$, SHELX $[2,3]$, \\
& WinGX/ORTEP [4] \\
\hline
\end{tabular}

Vertex 70v FTIR Spectrometer from 4000 to $400 \mathrm{~cm}^{-1}$. The ${ }^{1} \mathrm{H}$ and ${ }^{13} \mathrm{C}\left\{{ }^{1} \mathrm{H}\right\}$ NMR spectra were recorded at room temperature in $\mathrm{CDCl}_{3}$ solution on a Bruker Ascend $400 \mathrm{MHz}$ NMR spectrometer with chemical shifts relative to tetramethylsilane.

Synthesis: Tetra(4-chlorophenyl)tin was synthesized from the reaction of stannic chloride (Fluka) with 4chlorophenylmagnesium bromide (Fluka) in a 1:4 molar ratio. Tetra(4-chlorophenyl)tin $(0.57 \mathrm{~g}, 1 \mathrm{mmol})$ and 4(dimethylamino)pyridine hydrobromide perbromide (SigmaAldrich, $0.36 \mathrm{~g}, 1 \mathrm{mmol})$ were dissolved in ethanol $(50 \mathrm{~mL})$. The resulting mixture was stirred at room temperature until a colourless solution was obtained. 4,4'-Dimethyl-2,2'-dipyridyl (Sigma-Aldrich, $0.18 \mathrm{~g}, 1 \mathrm{mmol}$ ) in ethanol ( $5 \mathrm{~mL}$ ) was added to the mixture which was then refluxed for $2 \mathrm{~h}$. After filtration, the filtrate was evaporated slowly until colourless crystals formed. The crystals were filtered, washed with a minimum amount of hexane and air-dried. Yield: $0.34 \mathrm{~g}$ (50.6\%). M.pt: 395-397 K. IR ( $\left.\mathrm{cm}^{-1}\right) 1644$ (s) v(C-N), 1561 (s) v(C-N), 509 (w) v(Sn-0). ${ }^{1} \mathbf{H}$ NMR $\left(\mathrm{CDCl}_{3}\right.$, p.p.m.): $\delta$ 1.30 (s, 3H, ethanol- $\left.\mathrm{CH}_{3}\right) 2.43\left(\mathrm{~s}, 3 \mathrm{H}, \mathrm{CH}_{3}\right), 3.23\left(\mathrm{~s}, 2 \mathrm{H}, \mathrm{OCH}_{2}\right)$, $7.11(\mathrm{~d}, 6 \mathrm{H}, J=7.70, \mathrm{Ph}-\mathrm{H}), 7.59(\mathrm{~d}, 1 \mathrm{H}, J=6.50 \mathrm{~Hz}, \mathrm{py}-\mathrm{H})$, $8.11(\mathrm{~d}, 1 \mathrm{H}, J=6.82, \mathrm{py}-\mathrm{H}), 8.22(\mathrm{~s}, 1 \mathrm{H}, \mathrm{py}-\mathrm{H}), 8.53(\mathrm{~d}, 6 \mathrm{H}$, $J=7.68, \mathrm{Ph}-\mathrm{H})$; the hydroxy-O-H was not observed. ${ }^{13} \mathbf{C}\left\{{ }^{1} \mathbf{H}\right\}$ NMR $\left(\mathrm{CDCl}_{3}\right.$, p.p.m.): $\delta 21.2\left(\mathrm{CH}_{3}\right), 23.0\left(\mathrm{CH}_{3}\right), 40.2\left(\mathrm{OCH}_{2}\right)$, 116.7, 129.4, 135.4, $137.3(\mathrm{Ph}-\mathrm{H}), 122.1,124.6,139.0,149.0,156.2$ (py-H).

\section{Experimental details}

The C-bound $\mathrm{H}$ atoms were geometrically placed $(\mathrm{C}-\mathrm{H}=0.95-0.99 \AA)$ and refined as riding with 
Table 2: Fractional atomic coordinates and isotropic or equivalent isotropic displacement parameters $\left(\AA^{2}\right)$.

\begin{tabular}{|c|c|c|c|c|}
\hline Atom & $x$ & $y$ & $z$ & $U_{\text {iso }} * / U_{\text {eq }}$ \\
\hline Sn & $0.73807(2)$ & $0.34325(2)$ & $0.32425(2)$ & $0.01554(6)$ \\
\hline $\mathrm{Br} 1$ & $0.82458(3)$ & $0.50549(2)$ & $0.40150(2)$ & $0.02187(8)$ \\
\hline $\mathrm{Cl} 1$ & $1.32005(6)$ & $0.22787(6)$ & $-0.05566(5)$ & $0.03271(14)$ \\
\hline $\mathrm{Cl} 2$ & $0.12395(6)$ & $0.67606(5)$ & $0.10294(5)$ & $0.03057(14)$ \\
\hline $\mathrm{Cl} 3$ & $0.65562(9)$ & $0.07952(6)$ & $0.80098(5)$ & $0.04340(17)$ \\
\hline 01 & $0.65514(18)$ & $0.18457(13)$ & $0.26191(12)$ & $0.0192(3)$ \\
\hline $\mathrm{H} 10$ & $0.589(3)$ & $0.160(2)$ & $0.302(2)$ & $0.029 *$ \\
\hline N1 & $0.4237(2)$ & $0.11121(15)$ & $0.40045(16)$ & $0.0201(4)$ \\
\hline $\mathrm{C} 1$ & $0.6116(3)$ & $0.1884(2)$ & $0.15543(19)$ & $0.0262(5)$ \\
\hline $\mathrm{H} 1 \mathrm{~A}$ & 0.659181 & 0.243684 & 0.109560 & $0.031^{*}$ \\
\hline $\mathrm{H} 1 \mathrm{~B}$ & 0.496455 & 0.214307 & 0.155373 & $0.031^{*}$ \\
\hline $\mathrm{C} 2$ & $0.6636(4)$ & $0.0754(2)$ & $0.1101(2)$ & $0.0410(7)$ \\
\hline $\mathrm{H} 2 \mathrm{~A}$ & 0.777979 & 0.050722 & 0.107402 & $0.062^{\star}$ \\
\hline $\mathrm{H} 2 \mathrm{~B}$ & 0.629927 & 0.081345 & 0.038175 & $0.062^{\star}$ \\
\hline $\mathrm{H} 2 \mathrm{C}$ & 0.616754 & 0.020336 & 0.155270 & $0.062^{\star}$ \\
\hline C3 & $0.9358(2)$ & $0.30000(18)$ & $0.21079(17)$ & $0.0178(4)$ \\
\hline $\mathrm{C} 4$ & $1.0063(3)$ & $0.3850(2)$ & $0.16265(19)$ & $0.0232(5)$ \\
\hline $\mathrm{H} 4$ & 0.971705 & 0.458935 & 0.185578 & $0.028^{\star}$ \\
\hline C5 & $1.1256(3)$ & $0.3635(2)$ & $0.0822(2)$ & $0.0265(5)$ \\
\hline H5 & 1.172840 & 0.422038 & 0.050181 & $0.032^{\star}$ \\
\hline C6 & $1.1751(2)$ & $0.2558(2)$ & $0.04900(19)$ & $0.0228(5)$ \\
\hline $\mathrm{C} 7$ & $1.1093(3)$ & $0.1693(2)$ & $0.0961(2)$ & $0.0239(5)$ \\
\hline $\mathrm{H} 7$ & 1.145237 & 0.095355 & 0.073241 & $0.029^{\star}$ \\
\hline C8 & $0.9903(3)$ & $0.19163(19)$ & $0.17717(19)$ & $.0219(5)$ \\
\hline $\mathrm{H} 8$ & 0.945409 & 0.132342 & 0.210118 & $0.026^{\star}$ \\
\hline C9 & $0.5369(2)$ & $0.44804(17)$ & $0.25672(18)$ & $0.0169(4)$ \\
\hline C10 & $0.3869(2)$ & $0.46200(18)$ & $0.30821(18)$ & $0.0186(4)$ \\
\hline $\mathrm{H} 10$ & 0.371967 & 0.422596 & 0.375468 & $0.022^{\star}$ \\
\hline C11 & $0.2586(3)$ & $0.53288(19)$ & $0.26251(19)$ & $0.0206(4)$ \\
\hline $\mathrm{H} 11$ & 0.156574 & 0.542364 & 0.298043 & $0.025^{*}$ \\
\hline C12 & $0.2825(3)$ & $0.58921(19)$ & 0.1643 & $0.0214(5)$ \\
\hline C13 & $0.4308(3)$ & $0.5779(2)$ & $0.11177(19)$ & $0.0240(5)$ \\
\hline $\mathrm{H} 13$ & 0.445601 & 0.617902 & 0.044816 & $0.029^{\star}$ \\
\hline C14 & $0.5570(3)$ & $0.5070(2)$ & $0.15883(19)$ & $0.0226(5)$ \\
\hline H14 & 0.659006 & 0.498686 & 0.123521 & $0.027^{\star}$ \\
\hline C15 & $0.7096(2)$ & $0.25247(18)$ & $0.47340(17)$ & $0.0167(4)$ \\
\hline C16 & $0.7999(2)$ & $0.14475(19)$ & $0.49814(18)$ & $0.0202(4)$ \\
\hline $\mathrm{H} 16$ & 0.873449 & 0.107795 & 0.445433 & $0.024^{\star}$ \\
\hline C17 & $0.7837(3)$ & $0.09094(19)$ & $0.59844(19)$ & $0.0222(5)$ \\
\hline $\mathrm{H} 17$ & 0.846220 & 0.017788 & 0.615195 & $0.027^{\star}$ \\
\hline C18 & $0.6748(3)$ & $0.1455(2)$ & $0.67406(18)$ & $0.0228(5)$ \\
\hline C19 & $0.5814(3)$ & $0.2521(2)$ & $0.65189(19)$ & $0.0232(5)$ \\
\hline $\mathrm{H} 19$ & 0.506017 & 0.287884 & 0.704282 & $0.028^{*}$ \\
\hline C20 & $0.6009(3)$ & $0.30488(18)$ & $0.55139(18)$ & $0.0201(4)$ \\
\hline $\mathrm{H} 20$ & 0.538864 & 0.378333 & 0.535167 & $0.024^{\star}$ \\
\hline $\mathrm{C} 21$ & $0.4339(2)$ & $0.05090(18)$ & $0.49552(18)$ & $0.0178(4)$ \\
\hline $\mathrm{C} 22$ & $0.3257(3)$ & $0.08082(18)$ & $0.58212(19)$ & $0.0204(4)$ \\
\hline $\mathrm{H} 22$ & 0.338496 & 0.037974 & 0.648620 & $0.025^{\star}$ \\
\hline $\mathrm{C} 23$ & $0.1995(3)$ & $0.17291(19)$ & $0.5717(2)$ & $0.0218(5)$ \\
\hline$C 24$ & $0.1851(3)$ & $0.23137(19)$ & $0.4723(2)$ & $0.0239(5)$ \\
\hline $\mathrm{H} 24$ & 0.098688 & 0.293174 & 0.460424 & $0.029^{\star}$ \\
\hline $\mathrm{C} 25$ & $0.2991(3)$ & $0.19791(19)$ & $0.3907(2)$ & $0.0233(5)$ \\
\hline $\mathrm{H} 25$ & 0.288231 & 0.239204 & 0.323311 & $0.028^{*}$ \\
\hline $\mathrm{C} 26$ & $0.0870(3)$ & $0.2089(2)$ & $0.6659(2)$ & $0.0290(5)$ \\
\hline $\mathrm{H} 26 \mathrm{~A}$ & 0.129000 & 0.257287 & 0.706258 & $0.043^{*}$ \\
\hline $\mathrm{H} 26 \mathrm{~B}$ & 0.072418 & 0.142143 & 0.711514 & $0.043^{*}$ \\
\hline $\mathrm{H} 26 \mathrm{C}$ & -0.013938 & 0.250655 & 0.641314 & $0.043^{*}$ \\
\hline
\end{tabular}

$U_{\text {iso }}(\mathrm{H})=1.2-1.5 U_{\text {eq }}(\mathrm{C})$. The O-bound $\mathrm{H}$-atom was located in a difference Fourier map but, was refined with a distance restraint of $\mathrm{O}-\mathrm{H}=0.84 \pm 0.01 \AA$, and with $U_{\text {iso }}(\mathrm{H})$ set to $1.5 U_{\text {eq }}(0)$.

\section{Comment}

The title compound became available during recent studies of the binding of bis(substituted-benzyl)tin dihalides by molecules with potentially neutral, bridging ligands, such as 4,4'-bipyridyl- $N$-oxide [5]. The title compound is formulated as $\left\{\left(4-\mathrm{ClC}_{6} \mathrm{H}_{5}\right)_{3} \mathrm{Sn}\left[\mathrm{O}(\mathrm{H}) \mathrm{CH}_{2} \mathrm{CH}_{3}\right] \mathrm{Br}\right\}_{2}$ (4,4'-dimethyl-2,2'dipyridyl) (I), and was characterized by X-ray crystallography.

The molecular structures comprising the asymmetric unit of (I) are shown in the figure (50\% displacement ellipsoids; the full 4,4'-dimethyl-2,2'-dipyridyl molecule is generated by the application of the symmetry operation (i) $1-x,-y$, $1-z$ ). The tin atom in (I) is penta-coordinated by a bromide atom $[2.6050(3) \AA]$, three ipso-carbon atoms of the three 4chlorophenyl groups [Sn-C3, C9, C15 $=2.141(2), 2.131(2)$ and 2.119(2) $\AA]$ and the oxygen atom [2.4634(15) $\AA]$ of the ethanol molecule. The 4-chlorophenyl substituents occupy equatorial positions in a distorted trigonal-bipyramidal geometry. The $\mathrm{Br} 1-\mathrm{Sn}-01$ axial angle is $176.63(4)^{\circ}$, and the tin atom lies 0.2174(12) A out of the plane through the C3, C9 and C15 atoms in the direction of the $\mathrm{Br} 1$ atom. There are discrepancies in the angles subtended at the tin atom by the phenyl substituents with the angles subtended by the phenyl-C15 atom [C3-Sn$\mathrm{C} 15=124.36(8)^{\circ}$ and $\left.\mathrm{C} 9-\mathrm{Sn}-\mathrm{C} 15=119.12(8)^{\circ}\right]$ being systematically wider than the $\mathrm{C} 3-\mathrm{Sn}-\mathrm{C} 9$ angle $\left[113.42(8)^{\circ}\right]$. While the $\mathrm{C} 9-\mathrm{Sn}-\mathrm{C} 15$ is close to the ideal, the deviation from $120^{\circ}$ of the narrowest angle is correlated with the wide dihedral angle formed between the C3- and C9-rings, i.e. $60.40(7)^{\circ}$, suggesting minimal steric repulsion between them and hence, the narrow angle.

As indicated in the figure, there is an ethanol$\mathrm{O}-\mathrm{H} \cdots \mathrm{N}$ (pyridyl) hydrogen bond [01-H10 $\cdots \mathrm{N} 1$ : $\mathrm{H} 10 \cdots \mathrm{N} 1=1.98(3) \AA, 01 \cdots \mathrm{N} 1=2.807(2) \AA$ with angle at $\left.\mathrm{H} 1 \mathrm{O}=176(2)^{\circ}\right]$ between the title complex and the organic component of this co-crystal. Bonding parameters are in the expected ranges [6]. As the 4,4'-dimethyl-2,2'-dipyridyl is disposed about a crystallographic centre of inversion, a three-molecule aggregate ensues. Further stability to these aggregates is provided by $\pi \cdots \pi$ interactions between the chlorophenyl and pyridyl rings [inter-centroid $\mathrm{Cg}(\mathrm{C} 15-$ C20) $\cdots \operatorname{Cg}(\mathrm{N} 1, \mathrm{C} 21-\mathrm{C} 25)$ distance $=3.8951(14) \AA$ with angle of inclination $\left.=13.28(11)^{\circ}\right]$. The aggregates assemble in the crystal via a combination of weak non-covalent interactions. A supramolecular layer parallel to $\left(\begin{array}{lll}0 & 1 & 1\end{array}\right)$ is formed through the agency of chlorophenyl- $\mathrm{C}-\mathrm{H} \cdots \pi$ (chlorophenyl) interactions $\left[\mathrm{C} 19-\mathrm{H} 19 \cdots \mathrm{Cg}(\mathrm{C} 9-\mathrm{C} 14)^{\mathrm{ii}}\right.$ : $\quad \mathrm{H} 19 \cdots \mathrm{Cg}(\mathrm{C} 9-$ $\mathrm{C} 14)^{\mathrm{ii}}=2.98 \AA, \mathrm{C} 19 \cdots \mathrm{Cg}(\mathrm{C} 9-\mathrm{C} 14)^{\mathrm{ii}}=3.471(3) \AA$ with angle 
at $\mathrm{H} 19=114^{\circ}$ for symmetry operation (ii) $1-x, 1-y$, $1-z]$. The connections between layers to consolidate the three-dimensional architecture are of the type end-on chlorophenyl-C-Cl $\cdots \pi$ (chlorophenyl) [C12-Cl2 $\cdots \mathrm{Cg}(\mathrm{C} 3-$ C8 $)^{\mathrm{iii}:} \quad \mathrm{Cl} 2 \cdots \mathrm{Cg}(\mathrm{C} 3-\mathrm{C} 8)^{\mathrm{iii}}=3.4361(12) \AA$ with angle at $\mathrm{Cl} 2=142.34(8)^{\circ}$ for (iii) $\left.1-x, 1-y,-z\right]$ interactions.

Further insight into the molecular packing was achieved through an analysis of the calculated Hirshfeld surface employing Crystal Explorer 17 [7] and established procedures [8], including the calculation of the full and decomposed twodimensional fingerprint plots. The four major contributing contacts to the overall Hirshfeld surface (i.e. for both components of the asymmetric unit) are, in descending order $\mathrm{H} \cdots \mathrm{H}$ [33.2\%], Cl $\cdots \mathrm{H} / \mathrm{H} \cdots \mathrm{Cl}[25.3 \%], \mathrm{C} \cdots \mathrm{H} / \mathrm{H} \cdots \mathrm{C}$ [18.9\%] and $\mathrm{Br} \cdot \mathrm{H} / \mathrm{H} \cdots \mathrm{Br}[10.7 \%]$. There are several other contacts to the surface but, at distances at or greater than the sum of the respective van der Waals radii, such as $\mathrm{Cl} \cdots \mathrm{C} / \mathrm{C} \cdots \mathrm{Cl}$ [3.4\%], $\mathrm{Cl} \cdots \mathrm{Cl}[1.9 \%]$ and $\mathrm{N} \cdots \mathrm{H} / \mathrm{H} \cdots \mathrm{N}$ [1.6\%]. Subsequently, calculations were performed on the tin compound itself as well as upon the entire 4,4'-dimethyl-2,2'-dipyridyl molecule. For the former, the percentage contributions for the four most important contacts are, to a first approximation, the same, $\mathrm{H} \cdots \mathrm{H}[34.6 \%], \mathrm{Cl} \cdots \mathrm{H} / \mathrm{H} \cdots \mathrm{Cl}[26.9 \%], \mathrm{C} \cdots \mathrm{H} / \mathrm{H} \cdots \mathrm{C}$, $\mathrm{Br} \cdot \mathrm{H} / \mathrm{H} \cdots \mathrm{Br}[9.2 \%]$. As anticipated from the chemical composition, greater variations are not for the bipyridyl molecule, with significant increases to the surface of the molecule from $\mathrm{H} \cdots \mathrm{H}[41.9 \%]$ and $\mathrm{C} \cdot \mathrm{H} / \mathrm{H} \cdots \mathrm{C}$ [25.9\%] contacts complemented by notable decreases from $\mathrm{Cl} \cdots \mathrm{H} / \mathrm{H} \cdots \mathrm{Cl}[8.3 \%]$ and
$\mathrm{Br} \cdots \mathrm{H} / \mathrm{H} \cdots \mathrm{Br}[7.5 \%]$ contacts. Also, the relative importance of $\mathrm{N} \cdots \mathrm{H} / \mathrm{H} \cdots \mathrm{N}[6.3 \%]$ contacts increases.

Acknowledgements: Sunway University Sdn Bhd is thanked for financial support of this work through Grant No. STRRCTR-RCCM-001-2019.

\section{References}

1. Rigaku Oxford Diffraction: CrysAlis ${ }^{P R O}$. Rigaku Corporation, Oxford, UK (2018).

2. Sheldrick, G. M.: A short history of SHELX. Acta Crystallogr. A64 (2008) 112-122.

3. Sheldrick, G. M.: Crystal structure refinement with SHELXL. Acta Crystallogr. C71 (2015) 3-8.

4. Farrugia, L. J.: WinGX and ORTEP for Windows: an update. J. Appl. Crystallogr. 45 (2012) 849-854.

5. Lee, S. M., Lo, K. M.; Tiekink, E. R. T.: Crystal structure of bromido-tri(4-chlorophenyl- ${ }^{1} \mathrm{C}$ )-(ethanol- $\left.\mathrm{K}^{1} \mathrm{O}\right) \operatorname{tin}(\mathrm{IV})-$ 4,4'-dimethyl-2,2'-bipyridine (2/1), $\mathrm{C}_{52} \mathrm{H}_{48} \mathrm{Br}_{2} \mathrm{Cl}_{6} \mathrm{~N}_{2} \mathrm{O}_{2} \mathrm{Sn}_{2}$. Z. Kristallogr. NCS 235 (2019) 143-145.

6. Ng, S. W.; Das, V. G. K.: Outer-sphere coordination of $o$ phenanthroline in bis[aquachlorotri( $p$-chlorophenyl) tin.o-phenanthroline]. J. Organomet. Chem. 513 (1996) 105-108.

7. Turner, M. J.; McKinnon, J. J.; Wolff, S. K.; Grimwood, D. J.; Spackman, P. R.; Jayatilaka, D.; Spackman, M. A.: Crystal Explorer v17. The University of Western Australia, Australia (2017).

8. Tan, S. L.; Jotani, M. M.; Tiekink, E. R. T.: Utilizing Hirshfeld surface calculations, non-covalent interaction $(\mathrm{NCl})$ plots and the calculation of interaction energies in the analysis of molecular packing. Acta Crystallogr. E75 (2019) 308-318. 